\title{
LIPASE-CATALYZED TRANSESTERIFICATION OF PALM KERNEL OIL WITH DIALKYLCARBONATES
}

\author{
${ }^{1}$ Tjahjono Herawan and ${ }^{2}$ M. Rüsch Gen. Klaas \\ ${ }^{1}$ Product Development and Quality Research Group, Indonesian Oil Palm Research Institute (IOPRI), \\ Jl. B. Katamso Nr. 51 Medan 20158-Indonesia \\ ${ }^{2}$ Department of Technology, University of Applied Sciences Emden-Leer, 26723 Emden-Germany
}

Received 2012-01-11; Revised 2012-05-24; Accepted 2014-05-06

\begin{abstract}
Lipase-catalyzed transesterifications-especially in a solvent-free medium-are important for industrial applications because such systems would have an enormous advantage by avoiding the problem of separation, toxicity and flammability of organic solvents. However, the organic solvent-free alcoholysis, especially methanolysis, does not give high conversions. The same problem also occurs when ethyl or methyl acetate are used as acyl acceptors. The main problems of lipase-catalyzed organic solvent-free alcoholysis are first, the solubility of the plant oil in the substrate or solvent and second, the fact that transesterification is an equilibrium reaction. Dialkyl carbonates, versatile compounds due to their chemical reactivity and physical properties, may provide an alternative to solve both problems. Using dialkyl carbonates transesterification is not an equilibrium reaction, because the intermediate compound immediately decomposes to carbon dioxide and an alcohol. Moreover, dialkyl carbonates (especially dimethyl carbonate) are cheap and widely available. For single step lipase-catalyzed transesterification of palm kernel oil, diakyl carbonates (in this case dimethyl and diethyl carbonate) gave better yields compared to those of short chain alcohols. The rate of ester formation with dialkyl carbonates as substrate was about 6-7 times higher than that obtained with short chain alcohols. The formation of esters was gradually increased by a higher enzyme amount from 5-20\% (w/w of oil) for $8 \mathrm{~h}$ reaction time. However from the economic point of view, an enzyme amount of $10 \%$ on the weight base of oil was proposed for further reaction. Generally, the highest ester formation was observed when a temperature of $60^{\circ} \mathrm{C}$ was used. However, in the case of dimethyl carbonate little difference was observed at reaction temperatures of 60 and $70^{\circ} \mathrm{C}$ and the reactions proceeded nearly identically. The esters formation increased drastically up to more than $70 \%$ when water was added up to $0.2 \%$. However, ester formation extremely decreased when more than $0.4 \%$ water was added. Formation of ester was lower when a hydrocarbon solvent was added to the system compared to that of when dialkyl carbonates were used as substrate and solvent. Candida antarctica in the immobilized was found to be effective for transesterifying palm ker nel oil with short-chain dialkyl carbonates with or without any added organic solvents.
\end{abstract}

Keywords: Lipase-Catalyzed Transesterification, Esters Formation Increased, Short-Chain Dialkyl Carbonates, Added Organic Solvents, Agriculture Lipid Feedstocks, Decomposes Immediately

\section{INTRODUCTION}

The transesterification of vegetable oils and animal fats to form esters has received considerable attention for several years. Various routes have been proposed for both chemical and enzymatic processes (Nelson et al., 1996; Otera and Nishikido, 2009; Drauz et al., 2012). The most interesting research today is focused on the Institute (IOPRI), J1. B. Katamso Nr. 51Medan 20158-Indonesia 
utilization of enzymes, normally lipases, for catalysing the synthesis of simple esters of vegetable oils or other agriculture lipid feedstocks with or without the presence of organic solvents (Iso et al., 2001; Soumanou and Bornscheuer, 2003). Lipasecatalyzed transesterification in a solvent-free medium would be important for industrial applications because such a system would have an enormous advantage by avoiding the problems of separation, toxicity and flammability of organic solvents. However, the organic solvent-free alcoholysis, especially methanolysis, does not give high conversions. The same problem also occurs when ethyl or methyl acetate are used as acyl acceptors.

There have been numerous studies that report transesterification reactions using lipases with and without organic solvents. Nelson et al. (1996) reportlipase-catalyzed production of methyl and ethyl ester from various sources of oil in hexane. Shimada et al. (1999) also report continuous conversion of vegetable oils to methyl esters using lipases as biocatalyst. Both of those groups used alcohols as raw material. The disadvantage for technical applications of this method is, that is an equilibrium reaction. Based on the transesterification of a fatty acids with an dialkyl carbonates which was first reported by Pioch et al. (1991), Warwel et al. (1999) carried out lipase-catalyzed conversion of plant oils with dialkyl carbonates which is not equilibrium reaction, because the intermediate compound (carbonic acid monoacyl ester) decomposes immediately to carbon dioxide and an alcohol (Fig. 1). By using high oleic sunflower oil and dimethyl carbonate $(150 \mathrm{mmol}$ plant oil/1 solvent $=15 \%$ w/w, $3 \mathrm{~g}$ of Novozyme $® 435)$, after 72 hat $50^{\circ} \mathrm{C}$, Warwel et al. (1999) obtained about $80 \%$ methyl esters. Based on this result, lipase-catalyzed transesterification using dialkyl carbonates, especially dimethyl or diethyl carbonate, may provide a general alternative for the transesterification of sensitive substrates such as tung oil, calendula oil or fish oil.

The method has later been further developed to reactive extraction, i.e., the simultaneous extraction and transesesterification of triglycerols (Klaas and Warwel, 2001) and applied for the extraction of particular fatty acid esters (Klaas and Meuer, 2004).

Some key aspects of lipase-catalyzed esters synthesis have been investigated and reported: The source of alkyl donor (Mittelbach, 1990, Mittelbach et al., 1995; Linko et al., 1994; Brunet et al., 1999), the role of water (Leitgeb and Knez, 1990; Jeong and Lee, 1997; Wehtje and Adlercreutz, 1997), the effect of temperature and pressure conditions (Iso et al., 2001; Athawale et al., 2003) and the effect of organic solvents (Amaya et al., 1995). Some of these key aspects were also investigated in the transesterification of palm kernel oil with dialkyl carbonates catalyzed by Novozyme ® 435.

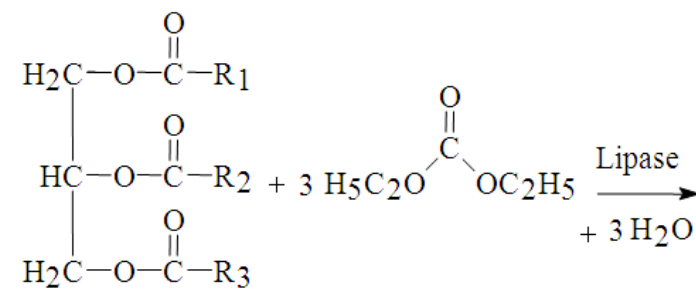<smiles>[R14]C(=O)OCCC</smiles><smiles></smiles>

Fig. 1. Transesterification of a triglyceride with dialkyl carbonates 


\section{MATERIALS AND METHODS}

Palm kernel oil was obtained from Indonesian Oil Palm Research Institute (IOPRI), Medan-Indonesia. Dimethyl carbonate, diethyl carbonate, methanol, ethanol and isohexane were analysis grade and purchased from Merck (Darmstadt, Germany). All solvents used were percolated through Puralox SCCa 150/145 N before use.N-Methyl-N-trimethylsilylheptaflour(o)Butyramide (MSHFBA) was used for sylilation and was obtained from Macherey-Nagel (Düren, Germany).

\subsection{Screening of Commercially Available Lipases for their Abilities to Transesterify the Triglyceride of Palm Kernel Oil}

In a $5 \mathrm{~mL}$ closed reaction tube containing $200.60 \mathrm{mg}$ $(0.286 \mathrm{mmol})$ of palm kernel oil in $0.8 \mathrm{~mL}$ isohexane, 3 mole equivalents of dialkyl carbonates or alcohols and the appropriate amount of enzyme were added. The reaction mixture was stirred for 24 hat $45^{\circ} \mathrm{C}$ in a heating block. The same method was also used without any added isohexane as solvent.

\subsection{Transesterification of Palm Kernel Oil with Dimethyl and Diethyl Carbonate Catalyzed by Novozyme ${ }^{\circledR} 435$}

In a $5 \mathrm{~mL}$ closed reaction tube containing various amounts of palm kernel oil, variousamounts of dialkyl carbonates and Novozyme ${ }^{\circledR} 435$ were added. The mixture was stirred and heated to $60^{\circ} \mathrm{C}$ for $24 \mathrm{~h}$. Samples were withdrawn at specified intervals during the 24 hreaction period. Samples were filtered (by Syringe filters; porosity $0.45 \mu \mathrm{m}, 4-\mathrm{mm}$ Nylon) to remove the enzyme and the excess of alkyl source was then evaporated. Filtrates were stored at $-20^{\circ} \mathrm{C}$ before further anaylsis.

\subsection{Analysis}

Lipid composition was analyzed by Gas Chromatography instrument (HP6890) equipped with a FID detector and a high temperature HT5 AQ (SGE), $12 \mathrm{~m} \times 0.22 \mathrm{~mm}$ i.d column. The film thickness was 0.1 $\mu \mathrm{m}$. Hydrogen flow was $40.0 \mathrm{~mL} \mathrm{~min}^{-1}$, airflow was $450 \mathrm{~mL} \mathrm{~min}^{-1}$ and make up flow (Nitrogen) was 45.0 $\mathrm{mL} \min ^{-1}$. The injector temperature was $400^{\circ} \mathrm{C}$, injector splitting was $10: 1$ and detector temperature was $420^{\circ} \mathrm{C}$. The oven temperature was programmed from $70^{\circ} \mathrm{C}(2$ minconstant) to $420^{\circ} \mathrm{C}$ at $10^{\circ} \mathrm{C} / \mathrm{min}$ and was held at $420^{\circ} \mathrm{C}$ for $6 \mathrm{~min}$. All sample were syllilated by $\mathrm{N}$ -
methyl-N-trimethylsilylheptaFluor(o)Butyramide (MSHFBA) containing methyl-imidazole $\left(50 \mu \mathrm{L} \mathrm{mL}^{-1}\right.$ MSHFBA) for about 30 minand afterwards the excess of MSHFBA was evaporated, the sample was dissolved in dichloromethane and directly inject to GC. Heptadecanoic acid methyl ester was used as internal standard.

\section{RESULTS}

\subsection{Screening of Commercially Available Lipases for their Abilities to Transesterify the Triglyceride of Palm Kernel Oil}

Several commercially available lipases were screened for their ability to transesterify palm kernel oil with dimethyl carbonate, diethyl carbonate and short chain alcohols such as methanol and ethanol. Reactions were done in isohexane at $45^{\circ} \mathrm{C}$ without any addition of water to find the most active lipases for transesterification.

The results show that among of several lipases tested, only the lipase preparations from Candida antarctica lipase B (Novozyme ${ }^{\circledR} 435$ and Candida B. on silica) were found to be most effective for transesterifying palm kernel oil with dimethyl or diethyl carbonate (34 and $31 \%$ yield respectively).

Even though the lipase from Candida antarctica lipase A (Chirazyme L-5), Pseudomonas fluorescens and Mucor miehei (Lipozyme ® RM IM and its unimmobilized form) were found effective for transesterifying palm kernel oil with ethanol to the corresponding ethyl esters derivatives (76, 73, 66 and $9 \%$ yield respectively), these lipase were not effective for transesterifying palm kernel oil either with diethyl carbonate $(0.71,0.24,0.93$ and $1.05 \%$ respectively) or dimethyl carbonate as shown in Fig. 2. Other lipases that were screened in this experiment, such as Carica papaya, Hog pancreas lipase andCandida cylindracea were not effective to transesterify palm kernel oil either with dialkyl carbonates or short chain alcohols, as shown in Fig. 2.

Several commercially available lipases were also tested for their ability to transesterify palm kernel oil with dimethyl carbonate in isohexane at an elevated temperatureof $60^{\circ} \mathrm{C}$. Again, among several lipases tested the lipases from Candida antarctica (Novozyme®435 and Candida B. Silica) were found most effective as shown in Fig. 3. The result also shows that at $60^{\circ} \mathrm{C}$, the methyl ester formation was higher than at $45^{\circ} \mathrm{C}$ as done in the first experiment described above. 
Tjahjono Herawan and M. Rüsch Gen. Klaas / American Journal of Applied Sciences 11 (8): 1212-1223, 2014

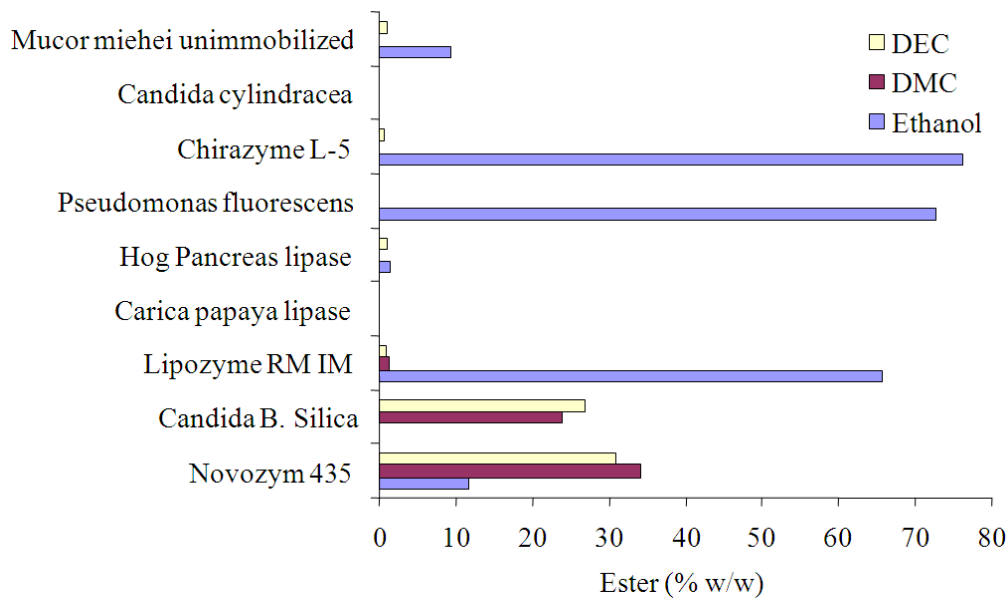

Fig. 2. Lipases' abilities to transesterify the triglyceride of palm kernel oil with Dimethyl Carbonate (DMC), Diethyl Carbonate (DEC) and ethanol at $45^{\circ} \mathrm{C}$ in Isohexane after $8 \mathrm{H}$

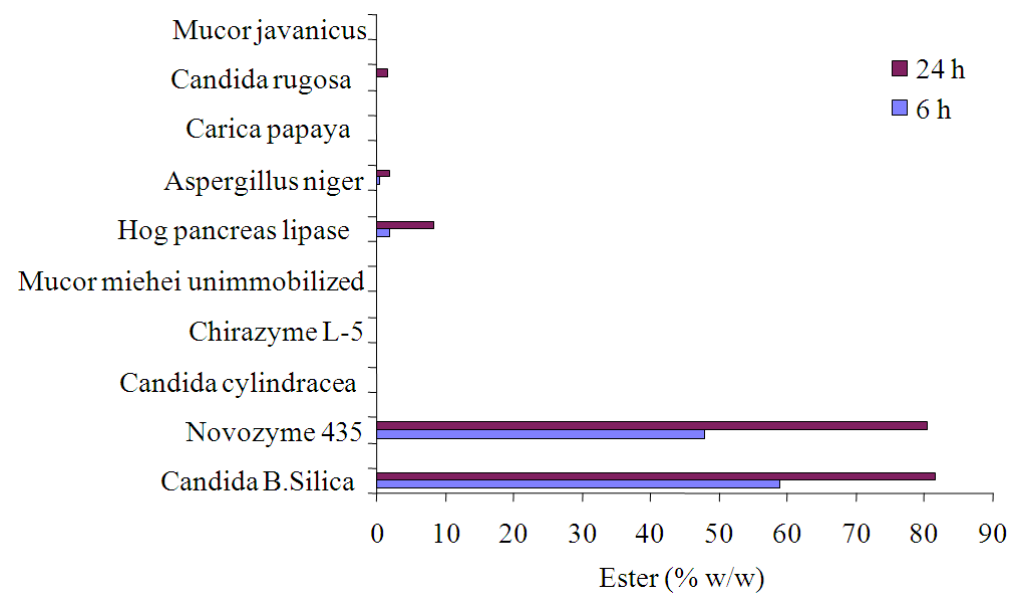

Fig. 3. Lipases' abilities to transesterify the triglyceride of palm kernel oil with dimethyl carbonate in isohexane at $60^{\circ} \mathrm{C}$ after 6 and $24 \mathrm{~h}$

A series of commercially available lipases was screened for their ability to transesterify palm kernel oil with dimethyl carbonate without another organic solvent at $60^{\circ} \mathrm{C}$. In this experiment, dimethyl carbonate at the same time acted both as substrate and solvent. The result shows that the lipase preparations from Candida antarctica (Novozyme ${ }^{\circledR} 435$ and Candida B. Silika) was the most effective for transesterifying palm kernel oil with dimethyl carbonate as shown in Fig. 4. Ester formation in the transesterification of palm kernel oil with dimethyl carbonate without another organic solvent was higher than that in the transesterification of palm kernel oil with dimethyl carbonate in isohexane.

\subsection{Transesterification of Palm Kernel Oil with Dimethyl and Diethyl Carbonate Catalyzed by Novozyme ${ }^{\circledR} 435$}

\subsubsection{Effect of the Alkyl Sources on the Esters Formation}

The type of alkyl source plays an important role in the reaction kinetics when enzymes are used as catalyst. Four alkyl donors were studied on the lipase-catalyzed transesterification with palm kernel oil. Transesterification with 1:3 (palm kernel oil/alkyl source) molar ratio was performed without any added solvent. The results show that among the alkyl donor 
used, the highest rate of ester formation was obtained using dialkyl carbonates as alkyl sources.

As shown in Fig. 5, using short chain alcohols such as methanol and ethanol as alkyl source, the rate of esters formation was low. After 8 hreaction time the formation of methyl and ethyl esters was only 11 and $12 \%$ respectively. The ester yields increased only slightly to 13 and $19 \%$ respectively, when the reaction time was extended to $24 \mathrm{~h}$. Even after $48 \mathrm{~h}$ the ester formation was not more than $30 \%$.

Completely different results were now found when dimethyl and diethyl carbonate were used as alkyl donors. As shown in Fig. 5, the ester formation rates with dialkyl carbonates were about 6-7 times higher than that with short chain alcohols. The formation of methyl and ethyl esters were about $40 \%$ after 1 hand reached up to 76 and $73 \%$ respectively after $8 \mathrm{~h}$. Then, the ester formation increased slowly to 83 and $81 \%$ respectively when reaction was prolonged to $24 \mathrm{~h}$.

\subsection{Effect of the Substrate Molar Ratio on the Esters Formation}

To ensure that the reaction proceeds rapidly and completely, the enzyme should not be inhibited by substrate concentration. Various substrate molar ratios were tested to understand their effect on the formation of esters.

As shown in Fig. 6, using dimethyl carbonate as substrate, the ester formation was low when a molar ratio of dimethyl carbonate/palm kernel oil lower than three (mol/mol) was used, because then the amount of dimethyl carbonate is not sufficient for a complete reaction. The ester formation increased with increasing molar ratio. The highest ester formation was obtained when the molar ratio of dimethyl carbonate/palm kernel oil was $20 \mathrm{moL}^{-1} \mathrm{~mol}(82 \%)$. However, the ester formation decreased when the molar ratio of substrate was higher than $100 \mathrm{moL}^{-1} \mathrm{~mol}$ (dissolution effect).

As shown in Fig. 7, using diethyl carbonate as solvent the highest ester formation was obtained with a molar ratio of diethyl carbonate/palm kernel oil of three $\mathrm{mol} / \mathrm{mol}$, i.e., the stoichiometric amount $(79 \%$ for 8 hours reaction). The formation of esters decreased with an increase in the molar ratio excess.

When the molar ratio of diethyl carbonate/palm kernel oil was $20 \mathrm{moL}^{-1}$, triglyceride conversion was complete after $8 \mathrm{~h}$, but the yield of ester was somewhat lower. Around $20 \%$ are converted to by-products (free fatty acids). The ester formation increased up to $93 \%$ with a corresponding decrease in free fatty acids when the reaction time was extended to $24 \mathrm{~h}$.

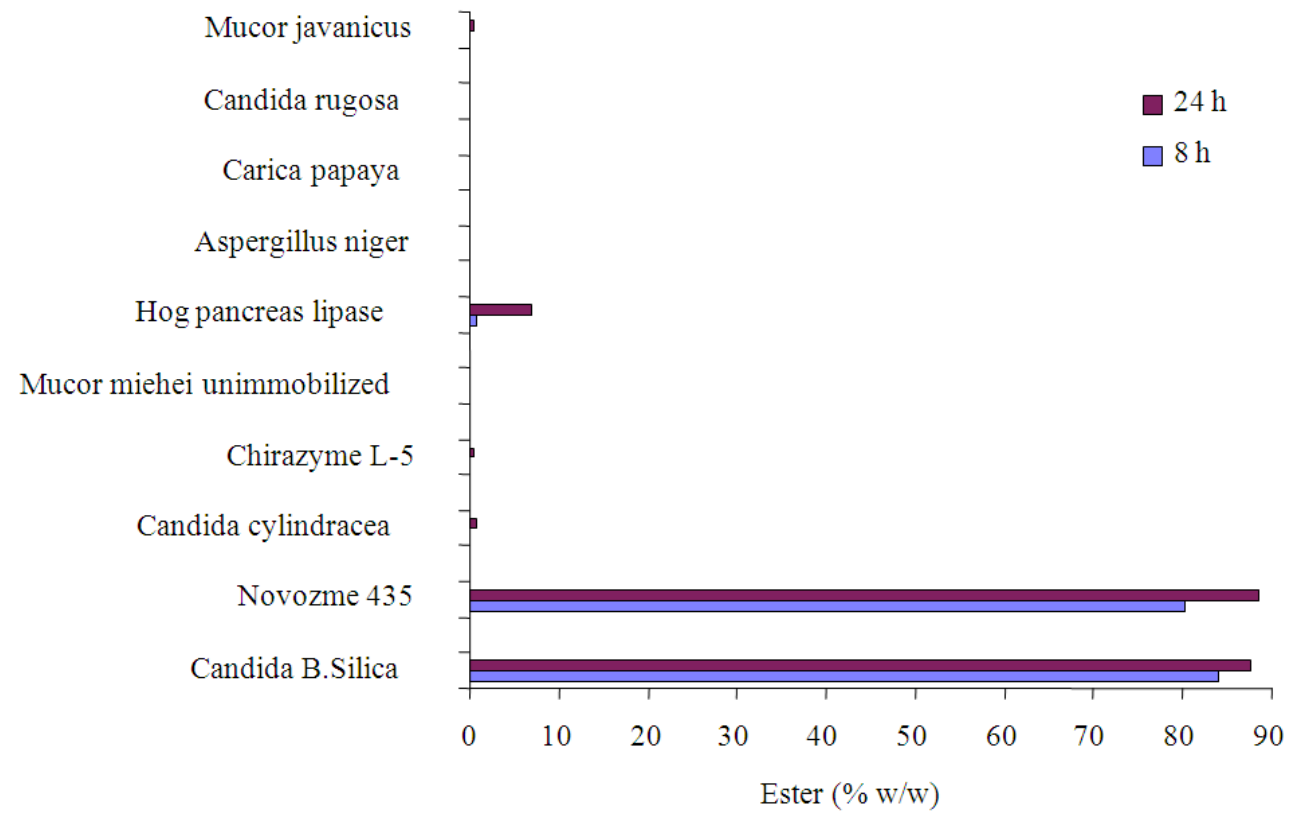

Fig. 4. Lipases' abilities to transesterify the triglyceride of palm kernel oil with dimethyl carbonate at $60^{\circ} \mathrm{C}$ after 8 and $24 \mathrm{H}$ 


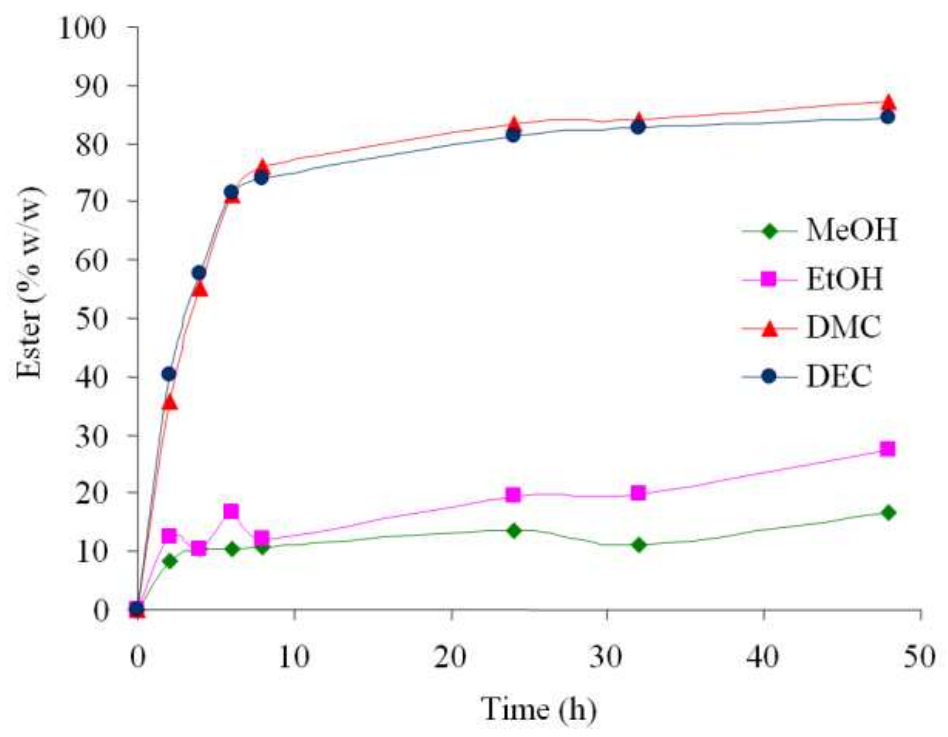

Fig. 5. Time course of transesterification of palm kernel oil with: Methanol, $\bullet$ Ethanol, $\Delta$ Dimethyl Carbonate, • Diethyl Carbonate, without organic solvent at $60^{\circ} \mathrm{C}$

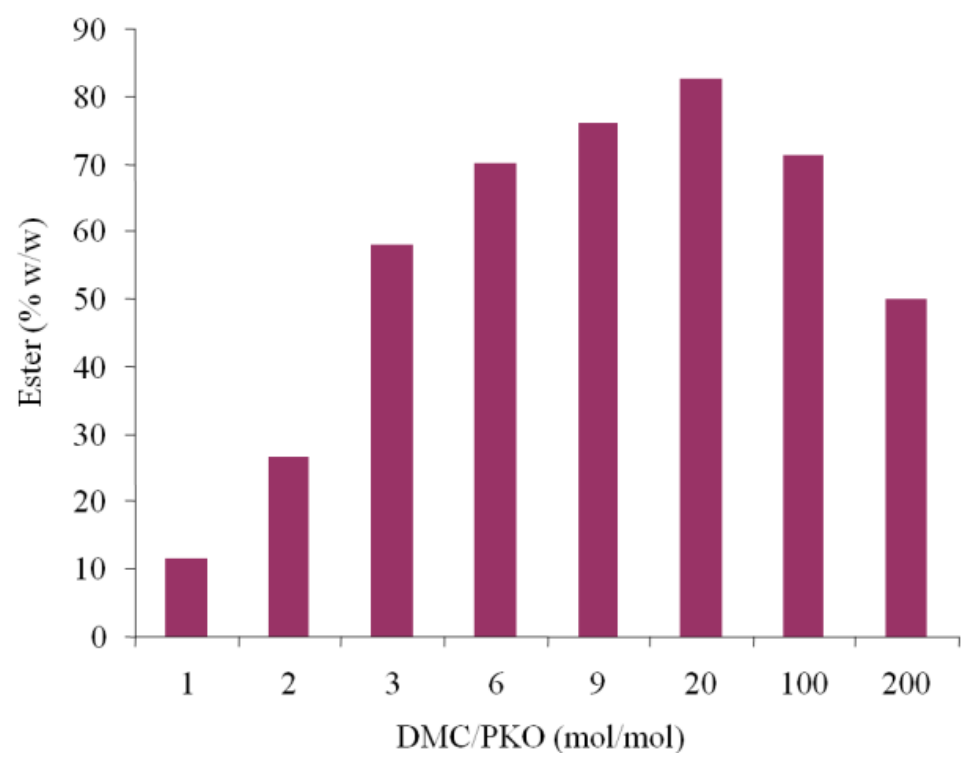

Fig. 6. Ester formation in the transesterification of palm kernel oil with dimethyl carbonate for various molar ratios of substrate at $50^{\circ} \mathrm{C}$ after $8 \mathrm{H}$

\subsection{Effect of the Amount of Novozyme ${ }^{\circledR} 435$ on the Ester Formation}

The amount of enzyme spent is a crucial economical factor for any successful industrial application. Therefore, the effect of the amount of enzyme on the transesterification of palm kernel oil with dialkyl carbonates was examined with tvarious amounts of enzyme in the range from $5-20 \%$ on the weight base of oil at $60^{\circ} \mathrm{C}($ Fig. 8).

There was a gradual increase in the formation of esters with increasing the enzyme amount from 5-12.5 
$\% \quad(w / w$ of oil) in the lipase-catalyzed transesterification of palm kernel oil with dimethyl carbonate after 8 hreaction time. When reaction time was prolonged to $24 \mathrm{~h}$, under all condition used the formation of esters reached nearlythe same value, whichindicates that the reaction was nearly finished.

The similar result was also found when diethyl carbonate was used as alkyl source instead of dimethyl carbonate. The formation of estergradually increased with the enzyme amount from $5-20 \%$ (w/w of oil) after $8 \mathrm{~h}$. Except for the lowest enzyme amount of 5\% (w/w of oil), the formation of esters reached nearly in the same value when the reaction time was extended to $24 \mathrm{~h}$ (Fig. 9).

For economic reasons an enzyme amount of $10 \%$ on the weight base of oil was used for further reaction. Under this condition, enzyme activity was $9.8 \mu$ $\mathrm{moL}^{-1}$ min.g (defined as the amount of substrate converted per gram of Novozyme ${ }^{\circledR} 435$ used).

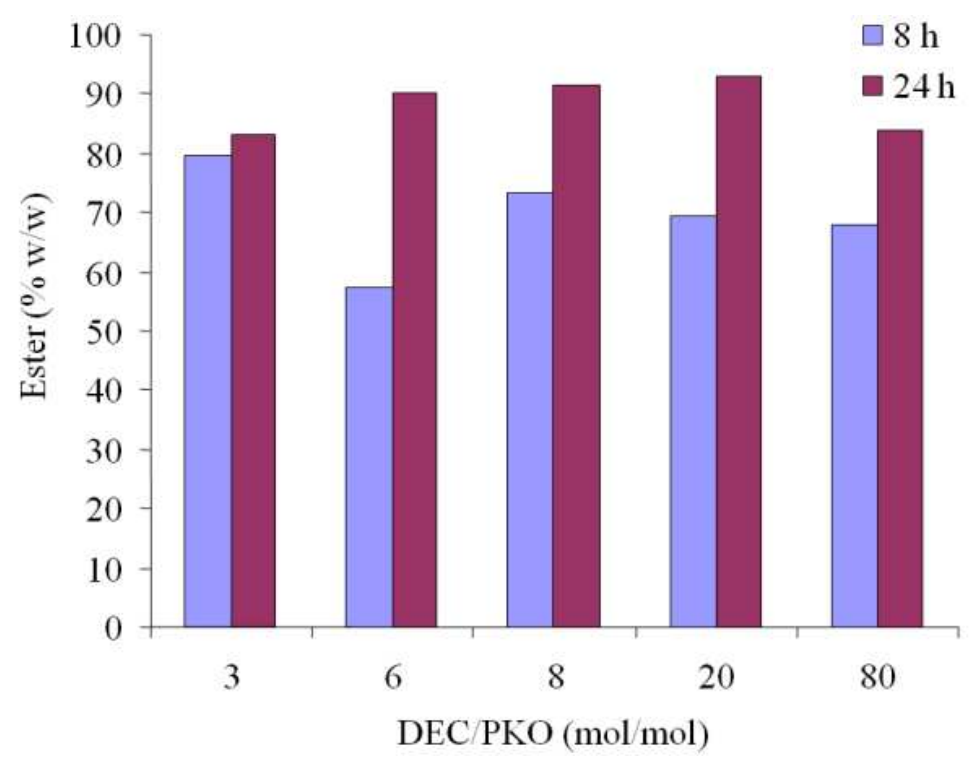

Fig. 7. Ester formation in the transesterification of palm kernel oil for various molar ratios of substrate / diethyl carbonate at $60^{\circ} \mathrm{C}$

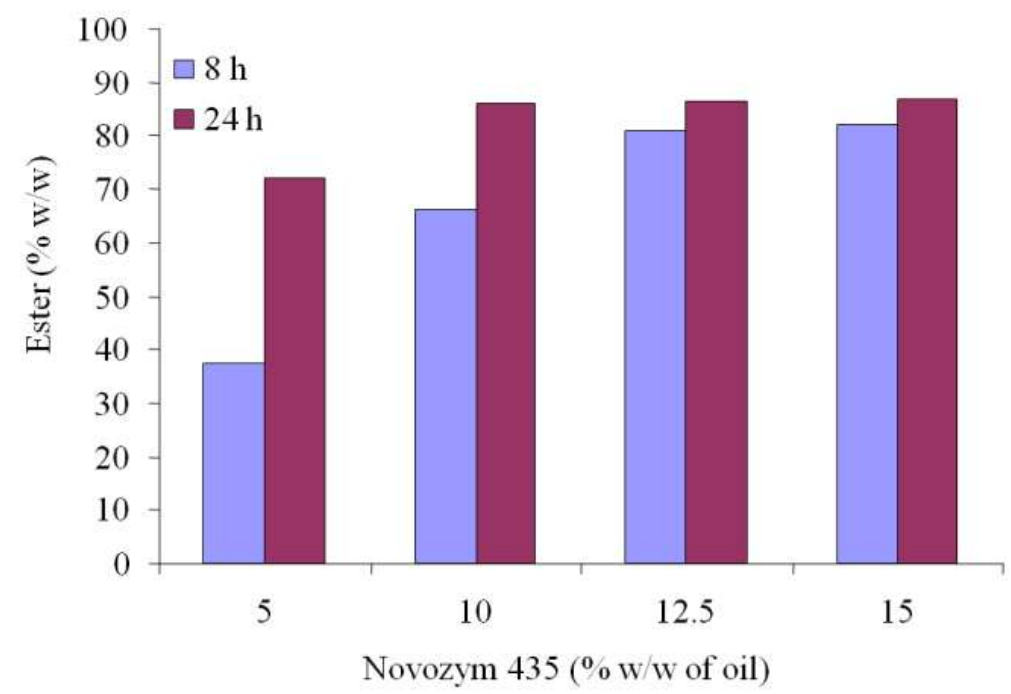

Fig. 8. Ester formation in the transesterification palm kernel Oil with dimethyl carbonate in the presence of various amounts of Novozyme ${ }^{\circledR} 435$ at $60^{\circ} \mathrm{C}$ 


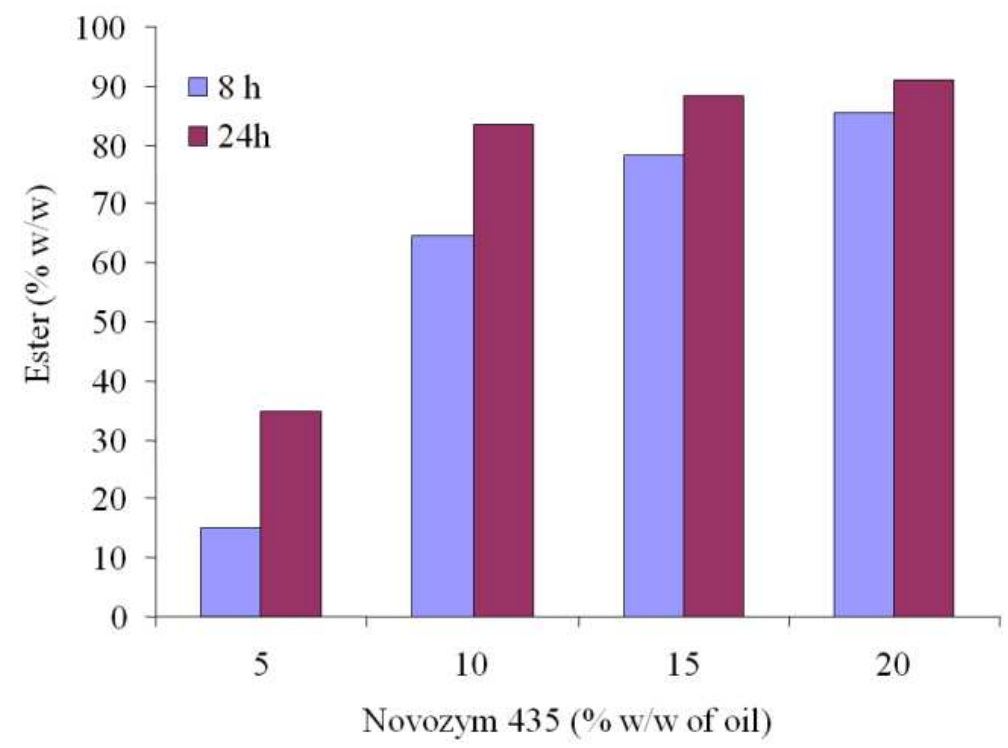

Fig. 9. Ester formation in the transesterification of palm kernel with diethyl carbonate in the presence of various amounts of Novozyme ${ }^{\circledR} 435$ at $60^{\circ} \mathrm{C}$

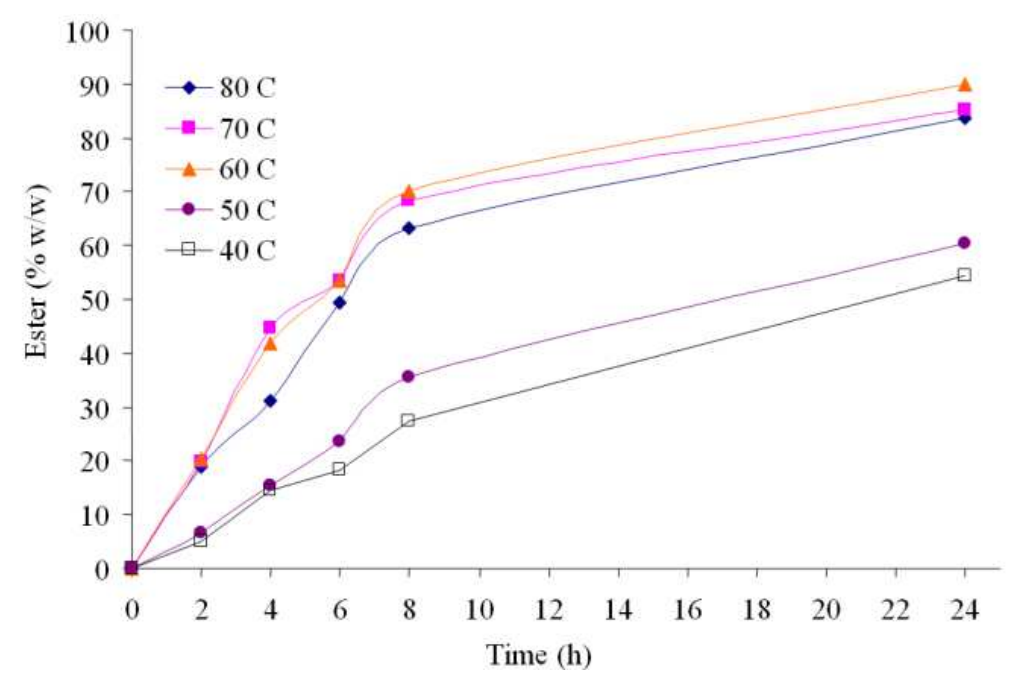

Fig. 10. Time course of the transesterification of palm kernel oil with dimethyl carbonate at various

\subsection{Effect of the Reaction Temperature on the Ester Formation}

Temperature is one of the important factors influencing enzyme activity. In general, the rate of a reaction increases with a rise in temperature. However, increasing the temperature leads to an enhanced mobility of protein segments in the enzymes while the strength of hydrophobic interaction decreases (Athawale et al., 2003).
The effect of the reaction temperature on the transesterification of palm kernel oil with dialkyl carbonates was examined in the temperature range of $40-80^{\circ} \mathrm{C}$. As shown in Fig. 10 using dimethyl carbonate as the alkyl source the highest ester formation was observed when a temperature of $60^{\circ} \mathrm{C}$ was used. The results for $\mathrm{t} 60$ and $70^{\circ} \mathrm{C}$ were very similar and the reaction proceeded nearly identically with about 70 and $68 \%$ of esters reached within $8 \mathrm{~h}$ respectively. However, the esters formation decreased slightly at temperatures of more than $70^{\circ} \mathrm{C}$. 
Different results were found when diethyl carbonate was used as alkyl source. As shown in Fig. 11, the formation of esters increased up to $64 \%$ when the temperature was raised up to $60^{\circ} \mathrm{C}$. But then the ester formation decreased when temperature was raised further to $70^{\circ} \mathrm{C}$.

\subsection{Effect of Water Addition on Ester Formation}

In order to investigate the effect of the water content as a factor limiting the activity of the catalyst, various amounts of water were added to the dialkyl carbonates before lipase-catalyzed transesterification of palm kernel oil with dialkyl carbonates was carried out.

The results show that the formation of esters was lowest when no water is added to the system, i.e., $13 \%$ after for $8 \mathrm{~h}$ reaction time. The ester formation increased drastically up to more than $70 \%$ when $0.2 \%$ (on the volume base of dimethyl carbonate) water was added. The formation of ester was faily constant in the range of $0.3-0.5 \%(\mathrm{v} / \mathrm{v})$. However, ester formation extremely decreased when $1.0 \%$ (v/v) water was added (Fig. 12).

A similar result was found when diethyl carbonate was used as substrate instead of dimethyl carbonate. As shown in Fig. 13, without any added water the formation of ester only reached $43 \%$. The highest ester formation, about $64 \%$, was found when $0.1-0.2 \%(\mathrm{v} / \mathrm{v})$ water was added to the diethyl carbonate. The formation of esters decreased when more than $0.4 \%$ (v/v) water was added.

The combined effect of temperature and water content on the ester formation is shown in Fig. 14. The highest ester formation was obtained with a water content of $0.2 \%$ and at $60^{\circ} \mathrm{C}$.

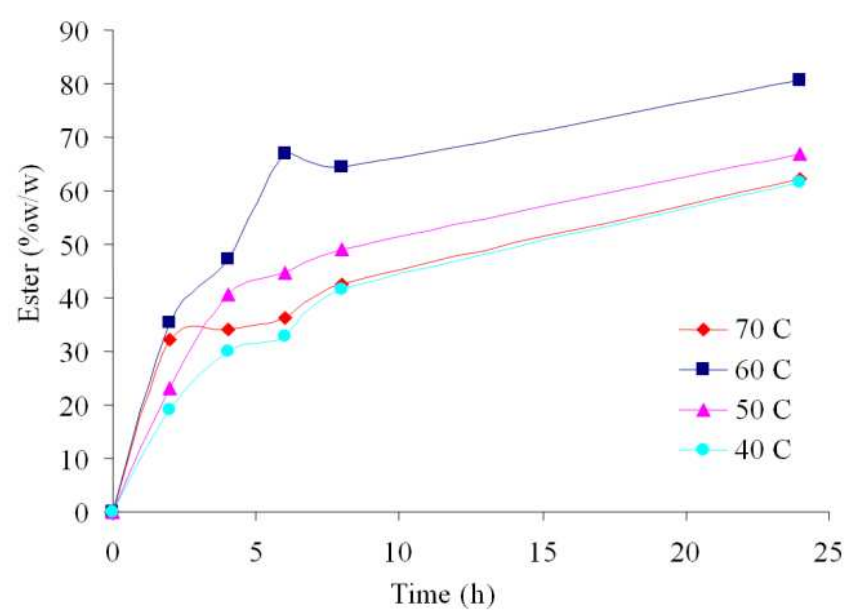

Fig. 11. Time course of the transesterification of palm kernel oil with diethyl carbonate at various temperatures

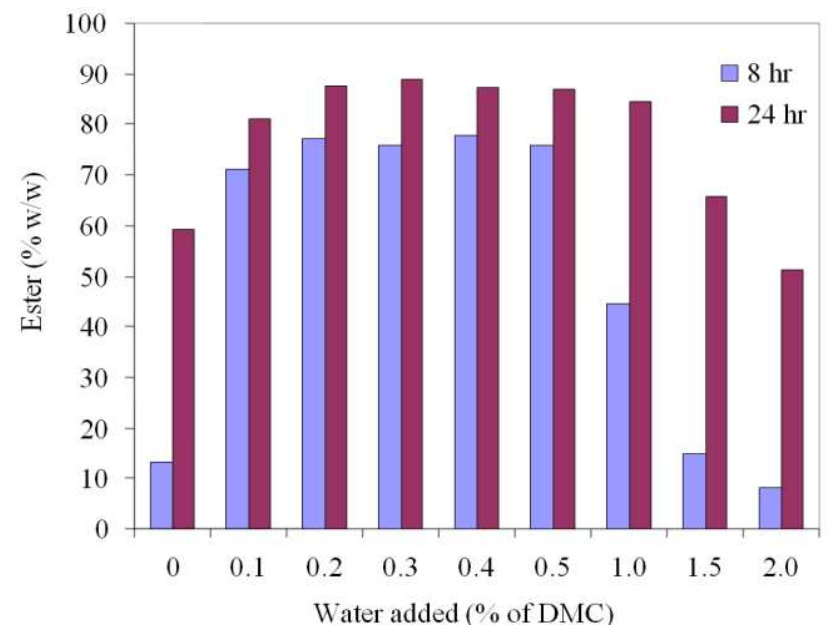

Fig. 12. Ester formation $(\% \mathrm{w} / \mathrm{w})$ in the transesterification of palm kernel oil with dimethyl carbonates containing various amounts of water 


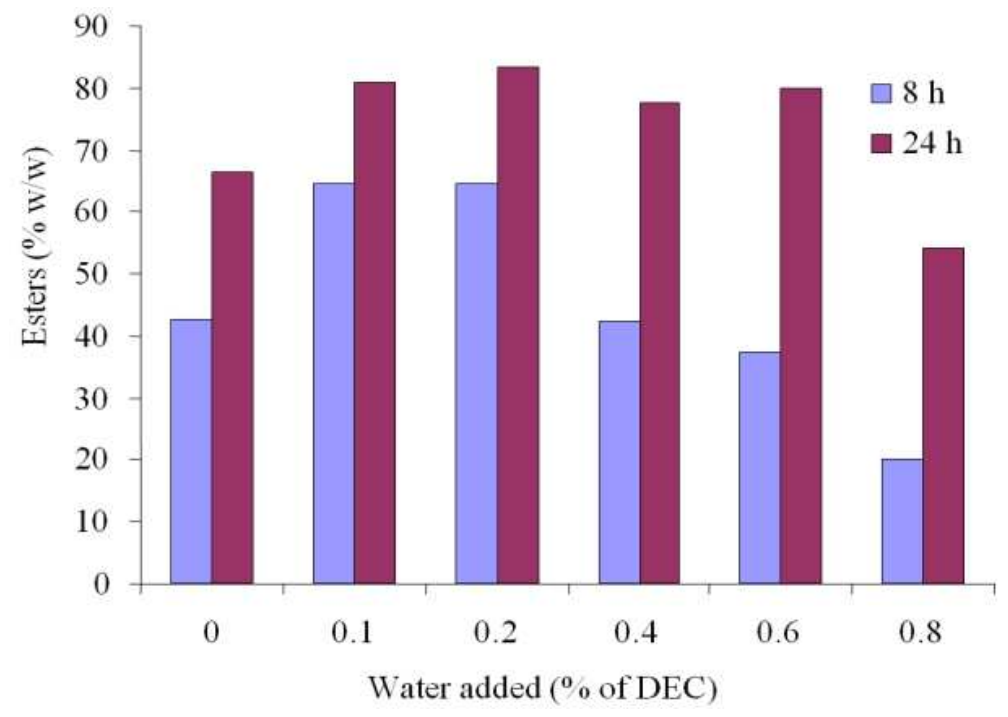

Fig.13. Ester formation $(\% \mathrm{w} / \mathrm{w})$ in the transesterification of palm kernel oil with diethyl carbonates containing various amounts of water

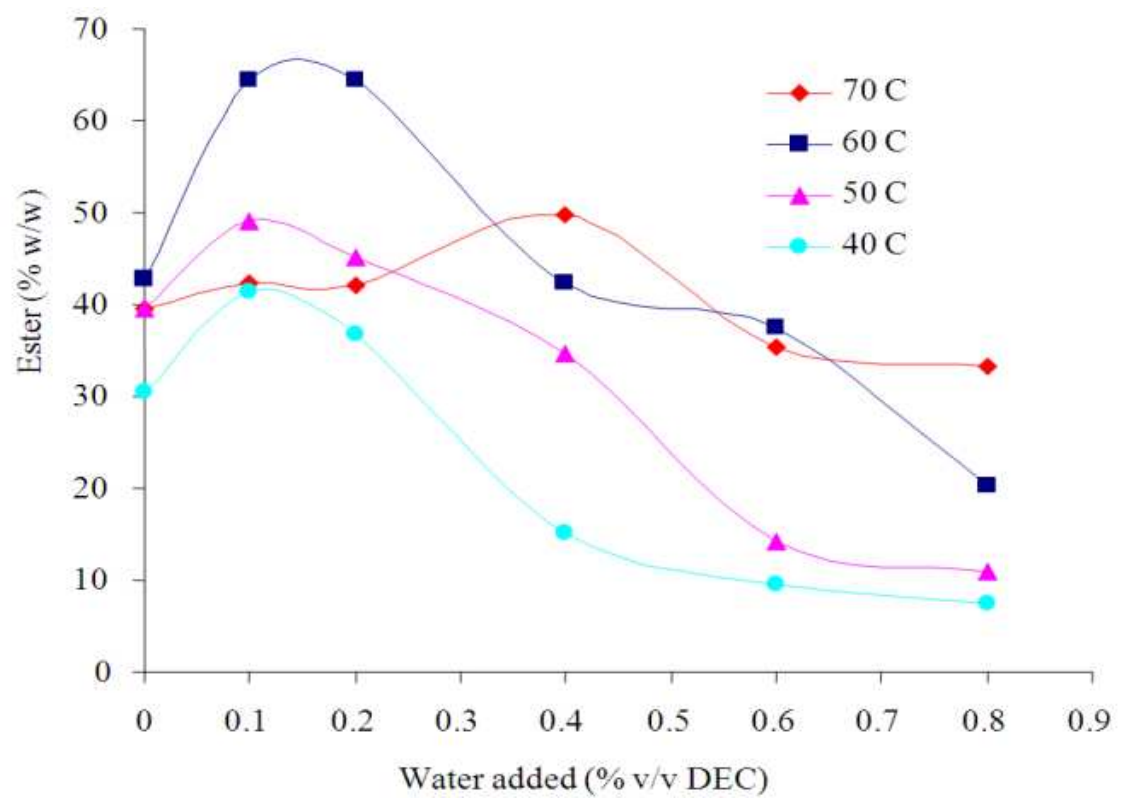

Fig. 14. Ester formation $(\% \mathrm{w} / \mathrm{w})$ on the transesterification of palm kernel oil with diethyl carbonates containing various amount of water

\section{DISCUSSION}

The lipase B from Candida antarcticawas found to be effective for transesterifying palm kernel oil with dimethyl or diethyl carbonate. The ineffectiveness of lipases from Candida antarctica lipase A (Chirazyme L5), Pseudomonas fluorescens and Mucor miehei (Lipozyme ® RM IM and its unimmobilized form) to transesterify palm kernel oil with dialkyl carbonates was only because dialkyl carbonates are poor substrates for these lipases and not because they are enzyme inhibitors'. This could be shown by transesterification of palm kernel oil with a mixture of ethanol and dimethyl carbonate (or a mixture of ethanol and diethyl carbonate) in the presence of isohexane as solvent and Lipozyme ® RM IM as biocatalyst. Under this 
conditions, ethyl ester yields were about 61 and $60 \%$ respectively. This value was not really different compared to that of ethyl esters produced only with ethanol as alkyl source (65\%) (Herawan, 2004).

Among the alkyl donors used, the rate of ester formation using dimethyl or diethyl carbonates was much higher than that obtained with methanol and ethanol. The high ester formation are consistent because when dialkyl carbonates are used as a substrate the reaction is not an equilibrium, because the intermediate compound decomposes immediately to carbon dioxide and alcohol (Fig. 1). Furthermore, palm kernel oil dissolves well in dialkyl carbonates. These results agree with those of Shimada et al. (1999) who found that a single addition of methanol to solvent-free alcoholysis catalyzed by Novozyme $\AA 435$ resulted in low conversion to methyl esters. Similar result were also reported by Hsu et al. (2002) who found that the same enzyme gave low conversion to esters (20-30\% after 48 $\mathrm{h}$ of reaction) in the transesterification of restaurant grease with ethanol. So, it is well known, that the lipasecatalyzed transesterification of a triglyceride with an alcohol is an equilibrium reaction and when short chain alcohol are used as a substrate, the two components did not dissolve well and the reaction cannot take place homogenously. Some papers reported that therefore an organic solvent is required for this reaction (Nelson et al., 1996; Iso et al., 2001). In conclusion for single step lipase-catalyzed transesterification of vegetable oils (like palm kernel oil), dialkyl carbonates (in this case dimethyl and diethyl carbonate) are much better substrates than short chain alcohols.

The formation of ester effected by molar ratios of substrate. Increasing molar ratio up to $20 \mathrm{moL} \mathrm{mol}^{-1}$ will increase the ester formation.This suggests that the water present in the enzyme preparation and in the system is a better nucleophile than diethyl carbonate and therefore, fatty acids are produced first and are then re-esterified by the enzyme with diethyl carbonate acting as nucleophile. It can be seen that dimethyl and diethyl carbonate behave differently. One reason might be that the coproduct methanol inhibits the enzyme activity whereas ethanol does not.

Enzyme catalysis in organic media is greatly influenced also by the environment of the enzyme. The organic solvent as well as the water content in the reaction medium affects the rate of catalysis (Torres and Otero, 1996; Wehtje and Adlercreutz, 1997). The amount of water present in the media is one of the critical parameters. When using enzymes in organic media some water is necessary for enzyme activity. Water in such a system is distributed between the enzyme, a carrier if present, the solvent, the substrate and the head space (Anthonsen and Hoff, 1998). As reported by Shah et al. (2004) as the water level increases, it increases the enzyme flexibility and the expressed activity. Above the optimum level of water, hydrolytic reactions become significant and transesterification yield is expected to go down (Shah et al., 2004). The whole topic has been recently excellently reviewed by Serdakowski and Dordick (2008).

\section{CONCLUSION}

Among several lipases screened, only the lipase B from Candida antarctica in the immobilized forms, namely Novozyme (® 435 and Candida B. Silica, was found to be effective for transesterifying palm kernel oil with short-chain dialkyl carbonates in isohexane at $45^{\circ} \mathrm{C}$. Novozyme ® 435 was also found to be the most effective lipase to transesterify palm kernel oil at $60^{\circ} \mathrm{C}$ without any added organic solvents.

For the single step lipase-catalyzed transesterification of palm kernel oil, diakyl carbonates (in this case dimethyl and diethyl carbonate) gave much better yields compared to of short chain alcohols. Generally, the highest ester formation was observed at $60^{\circ} \mathrm{C}$. The formation of esters was strongly influenced by the amount of water in the system.

\section{ACKNOWLEDGMENT}

Reachers acknowledge Institute for Lipid Research (BFEL) in Münster-Germany for Research facilities. T. Herawan acknowledge Indonesian Oil Palm Research Institute (IOPRI) for the leave of absence and scholarship provided for him since 2001 until 2004.

\section{REFERENCES}

Amaya, C.L., D. Stubbs and A.G. Marangoni, 1995. A new assay for lipase activity in organic solvent. Lipase-catalyzed synthesis of octyl-linolenate in a hexane microaqueous reaction system. Enzyme Microb. Technol., 17: 131-135. DOI: 10.1016/01410229(94)00052-S

Anthonsen, T. and B.H. Hoff, 1998. Resolution of derivatives of 1,2-propanediol with lipase $b$ from candida antarctica. Effect of substrate, medium, water activity and acyl donor on enantiometric ratio. Chem. Phys. Lipids, 93: 199-207. DOI: 10.1016/S0009-3084(98)00043-7 
Athawale, V., N. Manjrekar and M. Athawale, 2003. Effect of reaction parameter on synthesis of citronellyl methacrylate by lipase-catalyzed transesterification. Biotechnol. Prog., 19: 298-302. DOI: $10.1021 / \mathrm{bp} 0202867$

Brunet, C., M. Zarevucka, Z. Wimmer and M.D. Legoy, 1999. Lipase B from candida antarctica catalyses enantioselective transesterification of 2-(4Methoxybenzyl)-1-Cyclohexanols and 2-(4Methoxybenzyl)-1-cyclopentanols. Biotechnol. Lett., 21: 605-610. DOI: 10.1023/A:1005563617419

Drauz, K., H. Gröger and O. May, 2012. Enzyme Catalysis in Organic Synthesis. 1st Edn., John Wiley and Sons, Weinheim, ISBN-10: 3527325476, pp: 1985.

Herawan, T., 2004. Lipase catalyzed transesterification of plant oils with dialkyl carbonates. Ph.D. Thesis, RWTH Aachen.

Hsu, A., K. Jones, T.A. Flogia and W.N. Marmer, 2002. Immobilized lipase-catalysed production of alkyl esters of restaurant grease as biodiesel. Biotechnol. Applied Biochem., 36: 181-186. PMID: 12452801

Iso, M., B. Chen, M. Eguchi, T. Kudo and S. Shrestha, 2001. Production of biodiesel fuel from triglycerides and alcohol using immobilized lipase. J. Mol. Catalyst B, 16: 53-58. DOI: 10.1016/S1381-1177(01)00045-5

Jeong, J.C. and S.B. Lee, 1997. Enzymatic esterification reaction in organic media with continuous water stripping: Effect of water content on reaction performance and enzyme agglomeration. Biotechnol. Techniques., 11: 853-858. DOI: 10.1023/A:1018445829435

Leitgeb, M. and Z. Knez, 1990. The influence of water on the synthesis of n-butyl oleate by immobilized mucor miehei lipase. JAOCS, 67: 775-778. DOI: 10.1007/BF02540490

Linko, Y.Y., M. Lamsa, A. Huhtala and P. Linko, 1994. Lipase-catalyzed transesterification of rapeseed oil and 2-ethyl-1-hexanol. JAOCS, 71: 1411-1414. DOI: $10.1007 / \mathrm{BF} 02541364$

Mittelbach, M., 1990. Lipase-catalyzed alcoholysis of sun flower oil. JAOCS, 67: 168-170. DOI: 10.1007/BF02539619

Mittelbach, M., A. Silberholz and M. Koncar, 1995. Novel aspects concerning acid catalyzed alcoholysis of triglycerides. Proceedings of the 21st World Congress of the International Society for Fat Research, (SFR' 95). Hague (Netherland), pp: 497-499.

Nelson, L.A., T.A. Foglia and W.N. Marmer, 1996. Lipase-catalyzed production of biodiesel. JAOCS, 73: 1191-1195.DOI: 10.1007/BF02523383
Pioch, D., P. Lozano and J. Graille, 1991. First lipasecatalyzed synthesis of fatty carbonates ester. Biotechnol. Lett., 13: 633-636.DOI: 10.1007/BF01086317

Klaas, R.G.M. and P. Meurer, 2004. A Palmitoleic acid ester concentrate from seabuckthorn pomace. Eur. J. Lipid Sci. Technol., 106: 412-416. DOI: 10.1002/ejlt.200400968

Klaas, R.G.M. and S. Warwel, 2001. Reactive extraction of oilseed with dialkyl carbonates. Eur. J. Lipid Sci. Technol., 103: 810-814. DOI: 10.1002/14389312(200112)103:12<810::AIDEJLT810>3.0.CO;2-G

Otera, J. and J. Nishikido, 2009. Esterification: Methods, Reactions and Applications. 2nd Edn., John Wiley and Sons, Weinheim, ISBN-10: 3527627634, pp: 432.

Serdakowski, A.L. and J.S. Dordick, 2008. Activation Enzymes for Use in Organic Solvents. In: Organic Synthesis with Enzymes in Non Aqueous Media, Carrea, G. and S. Riva (Eds.)., John Wiley and Sons, Weinheim, ISBN-10: 3527621733, pp: 47-67.

Shah, S., S. Sharma and M.N. Gupta, 2004. Biodiesel preparation by lipase-catalyzed transesterification of jatropha oil. Energy Fuels 18 : 154-159. DOI: 10.1021/ef030075z

Shimada, Y., Y. Watanabe, T. Samukawa, A. Sugihara and H. Noda et al., 1999. Conversion of vegetable oil to biodiesel using immobilized candida antarctica lipase. JAOCS, 76: 789-793. DOI: 10.1007/s11746-999-0067-6

Soumanou, M.M. and U.T. Bornscheuer, 2003. Lipasecatalyzed alcoholysis of vegetable oils. Eur. J. Lipid Sci. Technol., 105: 656-660. DOI: 10.1002/ejlt.200300871

Torres, C. and C. Otero, 1996. Influence of the organic solvent on the activity in water and the conformation of candida rugosa lipase: Description of a lipaseactivity prereatment. Enzyme Microb. Technol., 19: 594-600. DOI: 10.1016/S0141-0229(97)82686-5

Warwel, S., M. Rüsch Gen. Klaas and R. Grothey, 1999. Lipase catalyzed conversions with diethyl and dimethyl carbonate in oleochemistry. Proceedings of the 6th Symposium Renewable Resources for the Chemical Industry, (RCI' 99), Bonn-Germany, pp: 93-105.

Wehtje, E. and P. Adlercreutz, 1997. Lipases have similar water activity profiles in different reactions. Biotechnol. Lett., 19: 537-540. DOI: 10.1023/A:1018385203375 